I. Nevliudov, O. Filipenko, O. Chala, I. Botsman

Kharkiv National University of Radio Electronics, Kharkiv

\title{
A METHOD OF MONITORING THE FUNCTIONAL SURFACES OF THE MICRO-OPTO-ELECTRO-MECHANICAL SYSTEMS' COMPONENTS
}

The article presents a method of control of functional surfaces of MOEMS elements of special purpose, which can be used in the technology of production of such structures. This method of non-destructive testing allows to obtain information about the parameters of the topology of the surface of functional structures, by eliminating the accompanying components in the interference signal. The method, in comparison with others, allows to increase the reliability of technological operations of production of functional surfaces of optical signal switches by more than $20 \%$ and to reduce labor costs up to 35\%. Using the proposed method, it is possible to give recommendations for improving the technological process of manufacturing MOEMS functional surfaces, to ensure the specified values of their topology. The modeling by means of computer processing is performed in the paper in order to determine the extremes of the bands of interference images of the functional surfaces of MOEMS elements.

Keywords: method, non-destructive control, optical component, batterword filter, moems, manufacturing defect.

\section{Introduction}

MEMS-technology of manufacturing optical mirrors involves the application of metal coatings mostly on a silicon base (to which metals can be added in small quantities to give certain properties).

Various metals, multilayer metal structures, metal silicide, glass enamels, polycrystalline silicon, carbon nanotubes, polymers and other materials are used as functional reflective surfaces. The use of several technological modes to obtain such structures, leads to all sorts of inevitable in them defects, introduced by the manufacturing technology [1].

The fact that the switching of the beam is carried out without converting light-electric signal-light, avoids limitations of the spectrum and distortion of the signal, but imposes additional, clear limitations and requirements for the quality of functional characteristics of reflective components and MOEMS in general.

The relevance of the study is due to the fact that despite the large number of experiments, proposed methods for analyzing the quality of functional elements, there is still the problem of ensuring the quality of such structures and processes.

There is no universal method, both for obtaining materials and quality control of such structures, control of their topology, which could be recommended as the best.

The used methods of linear processing are based on the developed theoretical basis, have high accuracy and wide functionality. However, in some cases, special methods of nonlinear computer processing of interference signals are appropriate [1].
The use of one or another approach depends on the type of interferometric problem to be solved and the following factors:

- the required accuracy of measurements and noise immunity of the system;

- the speed of the recording device and the computer system;

- the presence of independent channels for obtaining information about the characteristics of signals and external influences;

- the possibility of obtaining reliable a priori estimates of the parameters of interference images [1].

The proposed method of computer signal processing has a fairly high accuracy and wide functionality, does not require the use of specific equipment and allows you to analyze the qualitative micro characteristics of reflecting surfaces and obtain their three-dimensional image with the ability to cut (eliminate) noise and background components.

\section{Statement of basic materials}

Real interference signals can be represented for a one-dimensional case in the form [3]:

$s(x, \Theta)=s_{0}(x)+s_{m}(x) \cos \left[\varepsilon+2 \pi u_{0} x+\psi(x)\right]+n(x),(1)$

where $\Theta$ - the parameter vector;

$s_{0}(x)$ - the background component;

$\psi(x)$ - coefficient of phase fluctuations;

$n(x)$ - additive noise (white Gaussian noise).

In (1) there is a harmonic information component, which indicates the feasibility of processing interference signals in the frequency domain. 
Signal (1) is characterized by two important parameters - frequency $u_{0}$ and initial phase $\varepsilon$. In practice, there is the influence of a priori unknown parameters $s_{m}(x), \psi(x)$, and $s_{0}(x)$, and, as a result, the type of signal can change significantly.

This gives grounds for the use of nonparametric methods in computer processing of interference signals based on the Fourier transform apparatus: discrete (2) when processing the $N$-point sequence of the signal value $s(p)$ and discrete inverse transformation (3) to determine the periodicities in interference signals of the form:

$$
S(q)=\sum_{p=0}^{N-1} s(p) \exp (-j 2 \pi p q / N),
$$

$$
S(q)=\frac{1}{N} \sum_{p=0}^{N-1} s(p) \exp (-j 2 \pi p q / N) .
$$

Using the results of research on the pre-processing of the interference image, we took a two-dimensional distribution of the interference field formed by the functional layer of the optical switch, obtained the original data (Fig. 1, a). Fig. 1, a shows the presence of highfrequency and pulsed noise of the structure under study in the signal. We use an interactive environment for programming numerical calculations and visualization, which allows you to parse photos into a matrix of digital data. Fig. 1, b shows a fragment of the distribution of the amplitude of the interference field in the onedimensional version, fig. $1, \mathrm{c}-$ the signal with the noise component in the multidimensional version.

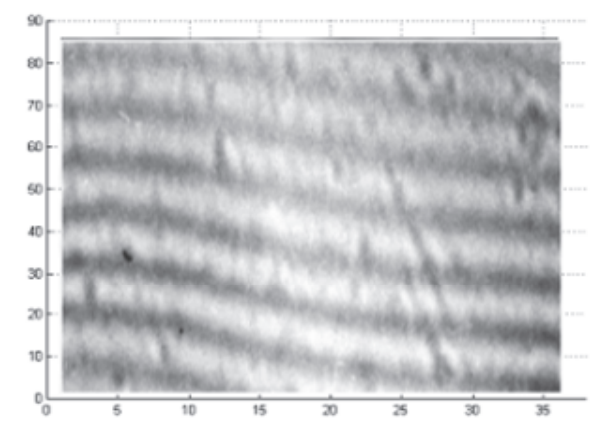

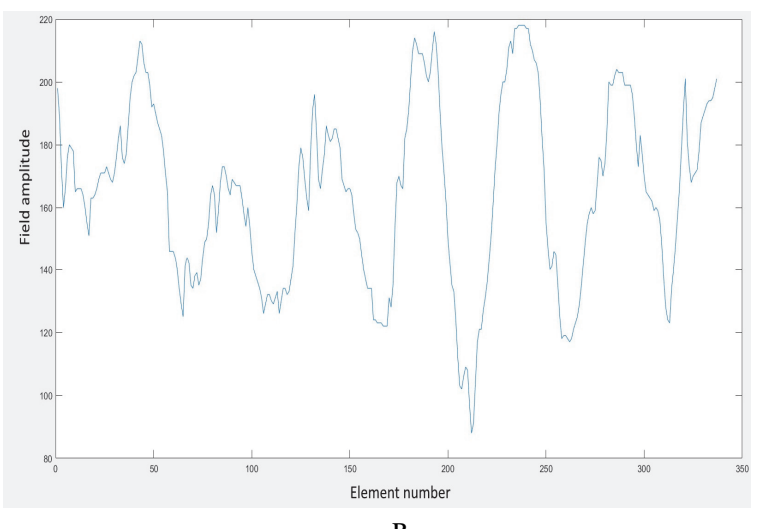

B

a

Fig. 1. Initial interference image of the fragment of the surface of the mirror under study a - interferogram of a fragment of the mirror surface;

$\mathrm{b}$ - the distribution of the amplitude of the interference field in the one-dimensional version; $\mathrm{c}-\mathrm{a}$ signal with a noise component in a multidimensional version

Taking into account that the signal has significant noise components, which do not allow to find reliable interference maxima for the obtained matrix and to minimize the noise components, it is necessary to filter the input signal.

The procedure of electronic filter synthesis includes two main stages. The first stage is an approximation - a procedure for obtaining a transfer function with a given accuracy: reproduces the specified frequency or time characteristics.

Let's use the Butterworth functions. The transfer function of the n-th order Butterworth low-pass filter is characterized by the expression (4):

$$
|H(j w)|^{2}=\frac{1}{1+w^{2 n}} .
$$

The amplitude-frequency characteristic of the Butterworth filter has the following properties:

1. At any $n$-th order the AFC value is $H\left(j_{0}\right)=1$.

2. At the cutoff frequency $\omega c\left(H\left(j_{0}\right)\right)=0,7$.

The AFC of the filter decreases monotonically with increasing frequency. For this reason, Butterworth filters are called filters with the flattest characteristics.

$$
|H(j w)|=\frac{1}{\sqrt{1+w^{2 n}}} \approx \frac{1}{w^{n}} .
$$


The order of the transfer function is determined by the approximate formula (6).

$$
n=20 \lg |H(j w)| / 20 \lg \left(w / w_{c}\right) .
$$

Fig. 2, a shows the filtered interference signal of the fragment using the Butterward filter, and fig. 2, b shows the noise allocation, fig. 2, c - the interference signal before filtering and after in the one-dimensional version for comparison.

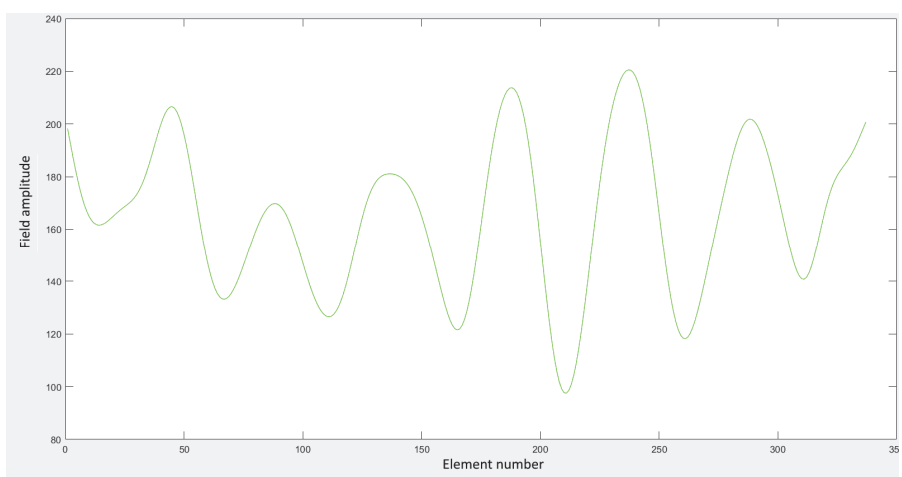

a

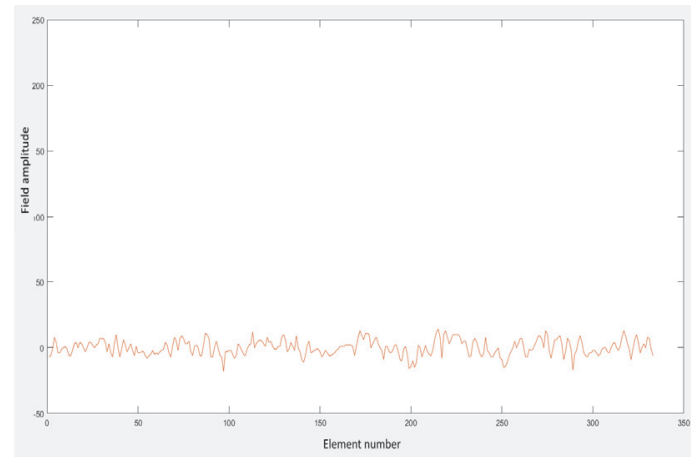

$\mathrm{b}$

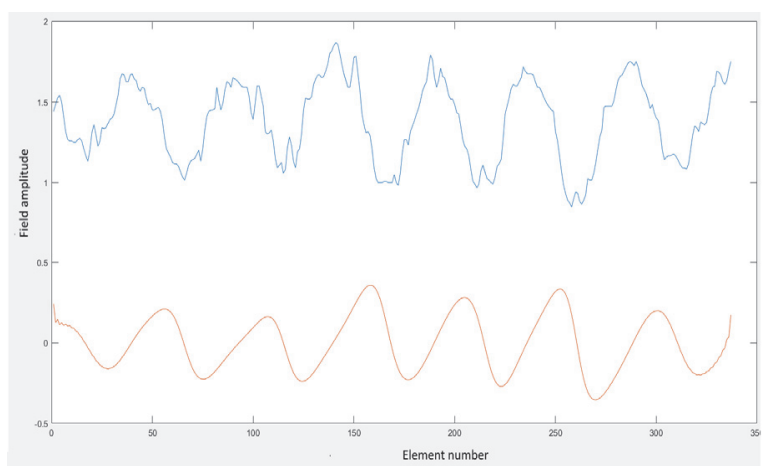

c

Fig. 2. The signal is filtered by the Butterward filter

Fig. 3 show a three-dimensional graph of the distribution of the amplitude of the interference field on the sample before filtering (a), after filtering - (b).

Obviously, the use of the Butterworth filter made it possible to smooth out the amplitude of the interference

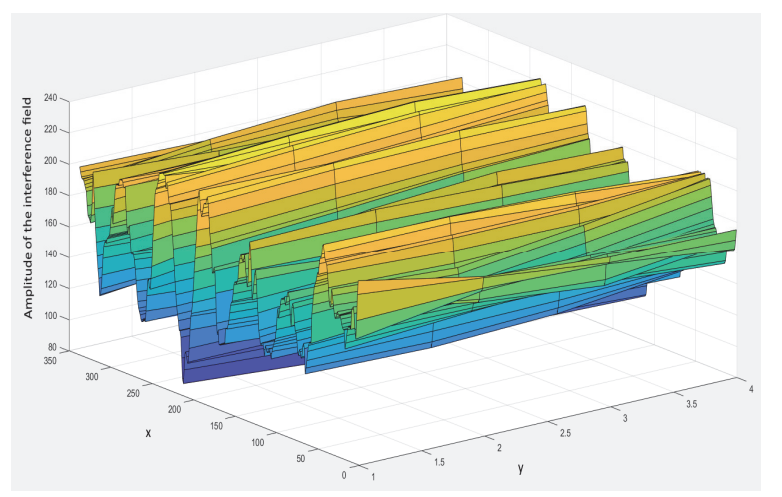

a field, almost eliminate the background, reduce the amount of noise at the border of the bands and between them, and increase the sharpness of the mirror sample under study, thereby improving accuracy in subsequent processing.

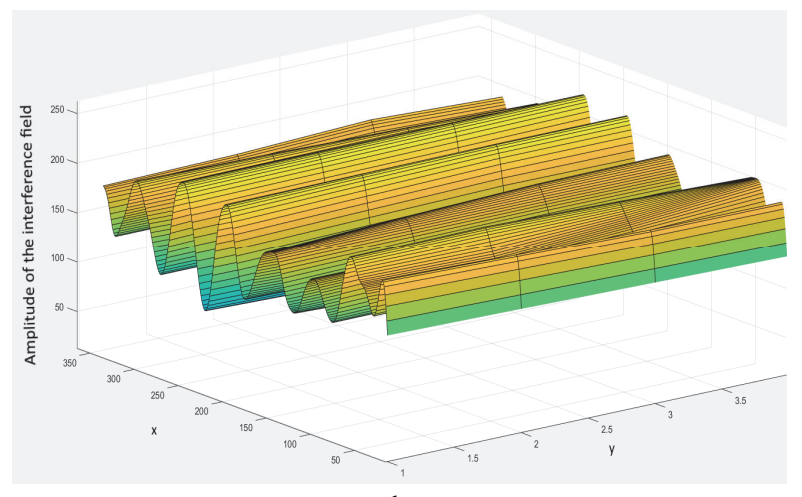

b

Fig. 3. Three-dimensional graph of the distribution of the amplitude of the interference field $a-$ before filtration; $b$ - after filtration

One of the problems that arise when processing interference signals is the uneven bypass $s_{m}(x)$ of the signal (1). It is a multiplicative interference that prevents accurate recovery of signal phase values. To 
eliminate the effect of this non-uniformity, a method can be used in which, regardless of the shape of the useful component of the signal, it is matched by a Gilbertlinked component having the same envelope $s_{0}(x)$. The obtained phase values do not depend on $s_{0}(x)$. Thus, the use of the Gilbert transform and the theory of analytical signals allows to reduce the influence of multiplicative noise and phase distortions of the interference signal.

The function $s_{c}(x)$ is valid, $-\infty<x<\infty$ then it can be aligned with the function $s_{S}(x)$ expressed by the Gilbert transformation $H\left\{s_{c}(x)\right\}$ :

$$
s_{s}(x)=H\left\{s_{c}(x)\right\}=\int_{-\infty}^{\infty} \frac{s_{S}(\xi)}{\pi(x-\xi)} d \xi
$$

or when using convolution characters:

$$
s_{S}(x)=s_{C}(x) *(1 / \pi x) .
$$

Using the Cauchy integral, namely $\lim _{x \rightarrow a} s(x)=\infty, b<a<c$, then the principal relation is determined as:

$$
\int_{b}^{c} s(x) d x=\lim _{x \rightarrow 0} \int_{b}^{a-c} s(x) d x+\int_{a+c}^{c} s(x) d x .
$$

The analytical signal is determined by a complex function:

$$
z(x)=s_{c}(x)+j s_{s}(x) .
$$

Expression for polar coordinates:

$$
z(x)=|z(x)| \exp [j \varphi(x)],
$$

where

$$
|z(x)|=\sqrt{s_{c}^{2}(x)+s_{s}^{2}(x)}=s_{m}(x)
$$

is the enveloping,

$$
\varphi(x)=\operatorname{arctg}\left[s_{s}(x) / s_{c}(x)\right]
$$

is the local phase of the signal

The local frequency is determined:

$$
u(x)=(1 / 2 \pi) /(d \varphi(x) / d x) .
$$

If the spectrum of the analytical signal is expressed as:

$$
Z(u)=F\{z(x)\}=F\left\{s_{c}(x)+j s_{s}(x)\right\}=S_{c}(u)+j S_{S}(u),
$$

then the inverse Fourier transform leads to the following result:

$$
z(x)=F^{-1}\{Z(u)\}=s_{c}(x)+j s_{s}(x) .
$$

The interference signal (1) is subjected to a Fourier transform to obtain a frequency spectrum whose components are centered relative to $\pm u_{0}$.

It should be noted that the Gilbert transformation is performed as a result of the inverse Fourier transform obtained only at positive frequencies. Therefore, the spectrum $Z(u)$ of the complex analytical signal $z(x)$ generated by the information component of the interference signal is described as

$$
Z(u)= \begin{cases}2 S_{c}, & u \geq 0 \\ 0, & u \leq 0\end{cases}
$$

The inverse Fourier transformation of $Z(u)=2 S_{c}(u), u>0$, obviously gives $z(x)$, at which $s_{s}(x)=\operatorname{Im}[z(x)]$.

The maxima of the filtered signal can be determined in several ways: to use the differentiation of the filtered signal or by means of Gilbert transformations. Fig. 4 shows markers that separate the area of the useful signal spectrum of the input signal.

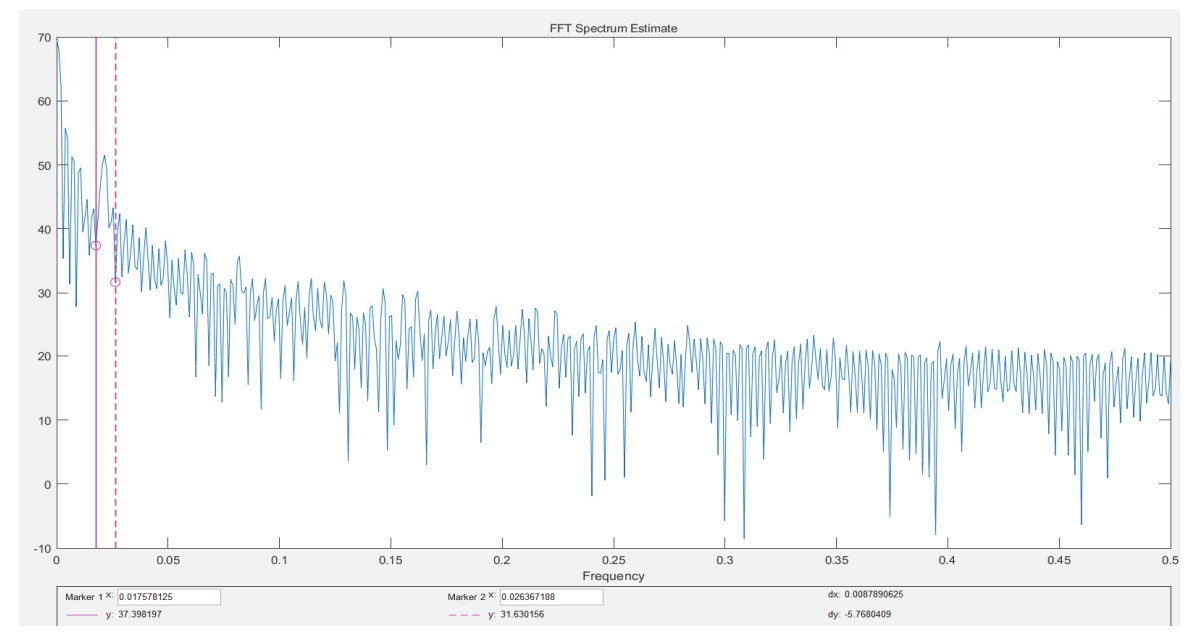

Fig. 4. Spectrum of the input signal 
As a result of the Gilbert transformation of the interference signal, the conjugate component $s_{S}(x)$ in the analytical signal is restored:

$$
z(x)=s_{c}(x)+j s_{s}(x)
$$

where

$$
\begin{aligned}
& s_{c}(x)=\operatorname{Re}\{z(x)\}=s_{m}(x) \cos \left[\varepsilon+2 \pi u_{0} x+\psi(x)\right], \\
& s_{S}(x)=\operatorname{Im}\{z(x)\}=s_{m}(x) \sin \left[\varepsilon+2 \pi u_{0} x+\psi(x)\right]
\end{aligned}
$$

quadrature components of (19) we obtain an estimate of the phase of the interference signal (1) performing the operation:

$$
\widehat{\varphi}(x)=\widehat{\varepsilon}+2 \pi u_{0} x+\widehat{\psi}(x)=\operatorname{arctg}\left[s_{s}(x) / s_{c}(x)\right]
$$

for all values of $x$. It should be borne in mind that in operation (20) the phase values are calculated taking into account all the frequency components of the signal, which is significant and significantly improves the quality of control.

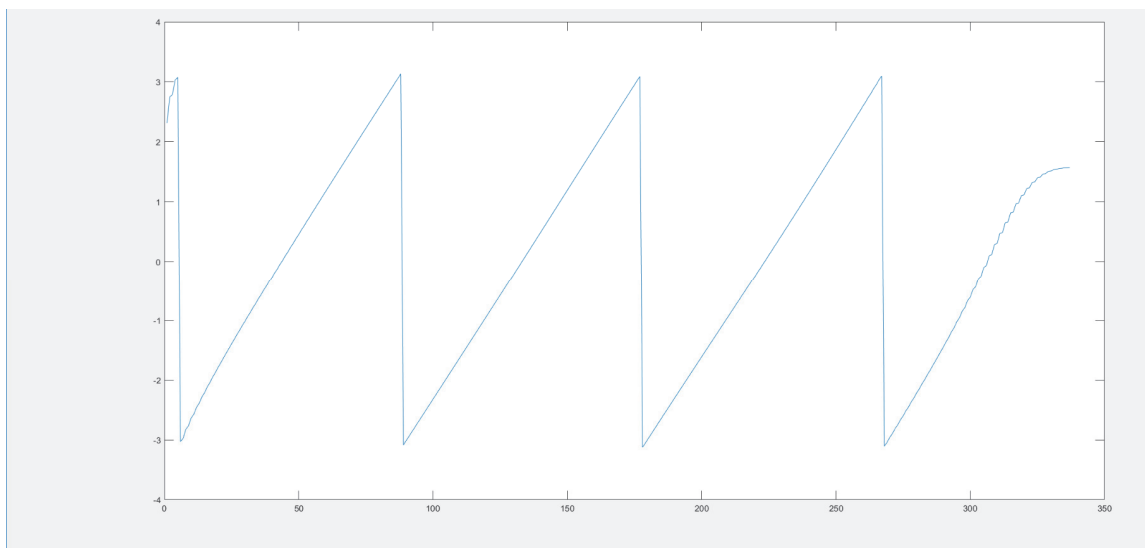

Fig. 5. Phase pattern

Fig. 6 shows the phase pattern, the filtered signal, and the input signal:

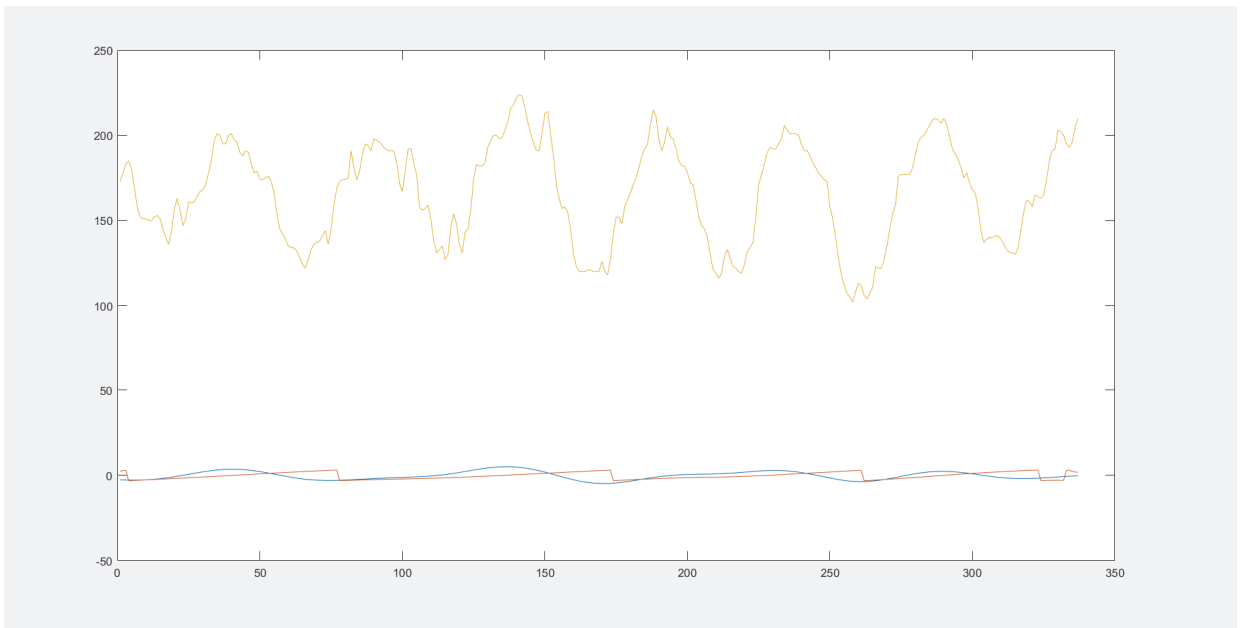

Fig. 6. Filtered signal, input signal, and phase pattern on one graph

As you can see from the graph, the 3rd order Butterworth filter has too "cut" signal amplitude, the filtered signal has a much smaller amplitude, so you need to reduce the order of the Butterworth function.
In practice the Hilbert transformations are performed on the basis of the FFT algorithm (fast Fourier transformation) using the relation (17), which connects the spectra of the analytical signal and the useful component of the interference signal $s_{c}(x)$.

It is important to study the errors of the recovery of the bypass and phase as a module and argument of the analytical signal.

When forming the analytical signal (10) using the relations (17) the condition of narrowband was implicitly assumed: the width of the spectrum of the signal (1) was small in comparison with the frequency, i.e.,

$$
\begin{gathered}
\hat{z}(x)=z(x)+\delta z(x)= \\
=(1 / 2 \pi) \int_{0}^{\infty}\left[S\left(u-u_{0}\right)+S\left(-u-u_{0}\right)\right] \exp (j 2 \pi u x) d u .
\end{gathered}
$$

After filtering the signal, using filters, we obtain its phase pattern (Fig. 5). 


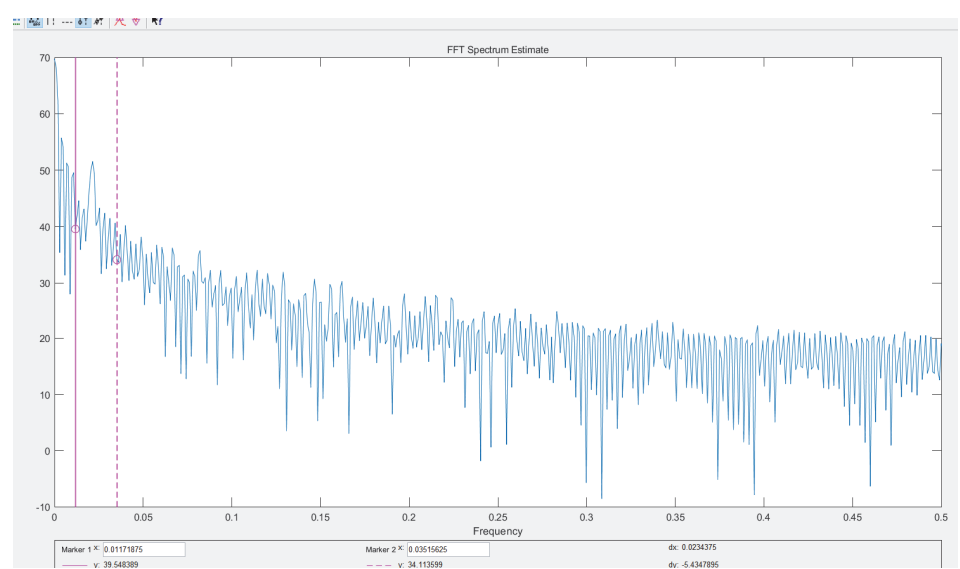

Fig. 7. Spectrum of the input signal with a selected useful signal

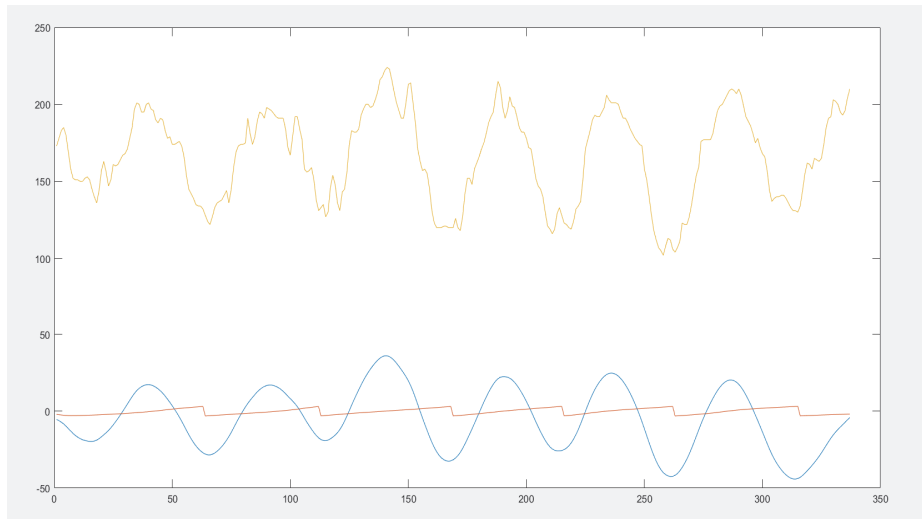

Fig. 8. Phase image of the input and filtered signals

As can be seen, using the 1st order Butterworth function to filter the input signal, the amplitude is also "killed", but within acceptable limits.

Also, it can be noted that the waveform repeats the input, so the spectrum of the useful signal is chosen correctly.

To determine the maxima, using the Gilbert transform, it is necessary to correlate the point at which the phase image is zero and the point of the filtered signal. The coordinates of these points correspond to the interference maxima from the matrix of the filtered signal.

Having received maxima of the filtered signal it is necessary to define RMS root mean square. Formula (22) for each column (interference band) according to the ISO standard.

$$
x_{r m s}=\sqrt{\frac{1}{n}\left(x_{1}{ }^{2}+x_{2}{ }^{2}+\ldots+x_{n}{ }^{2}\right)},
$$

where $x_{1} \ldots x_{n}$ is a set of numbers,

$n$ - quantity of numbers.

The obtained results show that the order of the Butterworth function and by changing $w_{n}, w_{k}$, it was found that it is necessary to apply a 1 st order filter and frequencies in the range from 0.08 to 0.35 .

Based on the results of the experiment, a "route" was constructed that represents the maxima of the intervention signal corresponding to the relief of the functional surface (topology) (Fig, 9).

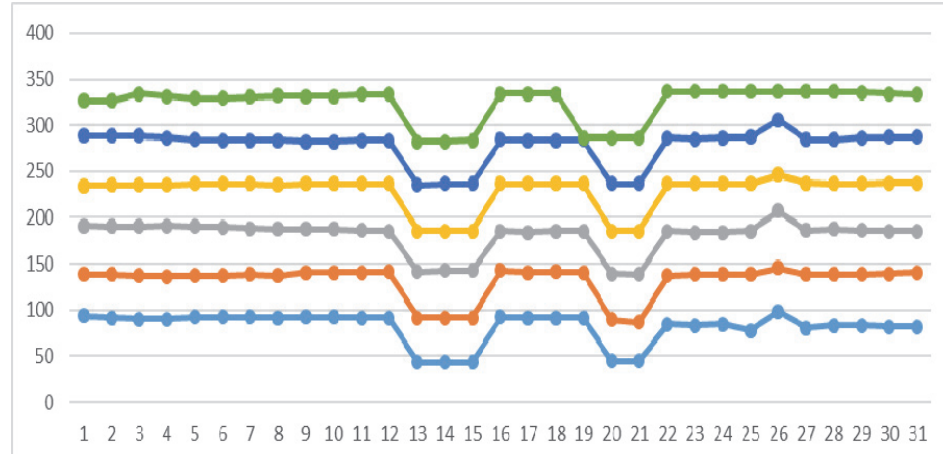

Fig. 9. The surface of the functional element of the studied MOEMS 


\section{Conclusions}

The article presents a method for controlling the functional surfaces of components of micro-optoelectro-mechanical systems, which is used to find the extremums of the bands of interference images of such structures.

The method can be used to assess the quality of the surface in the production of functional elements of micro-opto-electro-mechanical components.

The method allows to increase the level and reliability of technological operations of production of functional reflecting surfaces of micro-opto-electromechanical systems and the elements of electronic engineering.

\section{References}

1. Filipenko, O.I., Chala, O.O. and Videshyn, M.I. (2017), “Tekhnolohichni defekty vyrobnytstva kremniievykh pidkladok dlia funktsionalnykh vidbyvaiuchykh poverkhon MOEMS-peremykachiv" [Technological defects in the production of silicon substrates for functional reflective surfaces of MOEMS switches], Control, Navigation and Communication Systems, No. 2(42), PNTU, Poltava, pp. 61-63.

2. Fylypenko, O.I., Chala, O.O. and Videshyn, M.I. (2017), "Tekhnolohichni faktory vyrobnytstva, shcho vplyvaiut na yakist pokryttiv dzerkalnykh poverkhon MOEMS-peremykachiv" [Technological factors of production that affect the quality of coatings of mirror surfaces MOEMS-switches], Naukovi notatky, No. 57, pp. 178-183.

3. Vasylev, V.N. and Hurov, Y.P. (1998), "Kompiuternaia obrabotka syhnalov v prylozhenyy $k$ ynterferometrycheskym systemam" [Computer signal processing as applied to interferometric systems], BKhV-Sankt-Peterburh, Sankt Peterburg, 237 p.

4. Jiang, Y., Ma, W. and Zhao, Z. (2009), Adaptive Interference Cancellation System with Different Correlation Control Methods, 2009 International Conference on Intelligent Human-Machine Systems and Cybernetics, Hangzhou, Zhejiang, pp. 372-375, https://doi.org/10.1109/IHMSC.2009.216.

5. Suarez, J., Kravtsov, K. and Prucnal, P.R. (2011), Methods of Feedback Control for Adaptive Counter-Phase Optical Interference Cancellation, IEEE Transactions on Instrumentation and Measurement, Vol. 60, No. 2, pp. 598-607. https://doi.org/10.1109/TIM.2010.2051058.

6. Fylypenko, O.I. and Chala, O.O. (2014), "Konstruktyvnotekhnolohichni faktory vtrat v optychnykh peremykachakh na osnovi MOEMS-komponentiv" [Structural and technological factors of losses in optical switches on the basis of MOEMScomponents], Mizhnarodna naukovopraktychna konferentsiia "Radiotekhnichni polia, syhnaly, aparaty ta systemy", Kyiv, Ukraine.

7. Kim, S.J., Lee, J.Y., Lee, J.C., Kim, J.H., Lee, B. and Kim, N.Y. (2003), Adaptive feedback interference cancellation system (AF-ICS), Proc. IEEE MTT-S Int. Microw. Symp. Dig., Vol. 1, pp. 627-630.

8. Comtois, J.H., Michalicek, M.A., Clark, N. and Cowan, W. (1998), MOEMS for adaptive optics, 1998 IEEE/LEOS Summer Topical Meeting. Digest. Broadband Optical Networks and Technologies: An Emerging Reality. Optical MEMS. Smart Pixels. Organic Optics and Optoelectronics (Cat. No.98TH8369), Monterey, CA, USA, pp. II/95-II/96. https://doi.org/10.1109/LEOSST.1998.689742.

9. Kurihara, K., Takagi, H. and Maeda, R. (2012), Polymer MOEMS mirror by all vacuum-less processes combining printed film and injection molding replication, Symposium on Design, Test, Integration and Packaging of MEMS/MOEMS, Cannes, pp. 200-203.

10. Nevliudov, I., Bortnikova, V., Chala, O. and Maksymova, S. (2018), Modeling MEMS Membranes Characteristics, XXVI-th International Ukrainian-Polish Scientific and Technical Conference CAD in machinery design implementation and educational issues (CADMD), pp. 61-68.

11. Unamuno, A. and Uttamchandani D. (2005), Hybrid MOEMS tunable filter for interrogation of fiber Bragg grating sensors, IEEE Photonics Technology Letters, Vol. 17, No. 1, pp. 202-204. https://doi.org/10.1109/LPT.2004.837746.

12. Filipenko, A.I. (1998), A Method for Analyzing Radiation Intensity and its Application to Manufacture of Fiber Optic Components, Telecommunications and Radio Engineering, Vol. 52, No. 12.

13. Joannopoulus J.D., Meade, R.D. and Winn, J.N. (1995), Photonic Crystals, Princeton University Press.

14. Tortschanoff A., Baumgart, M., Holzmann, D., Mayer, C., Sandner, T. and Kenda, A. (2014), Optical position detection for MOEMS scanner mirrors with arbitrary trajectories, International Conference on Optical MEMS and Nanophotonics, Glasgow, pp. 135-136.

15. Filipenko, O., Chala, O., Bortnikova, V., Sychova, O. and Botsman, I. (2019), Impact of Technological Operations Parameters on Moems Components Formation, IEEE 8th International Conference on Advanced Optoelectronics and Lasers (CAOL), Sozopol, Bulgaria, pp. 371-374. https://doi.org/10.1109/CAOL46282.2019.9019570.

16. Koch, U., Hoessbacher, C., Emboras, A. and Leuthold, J. (2017), Optical memristive switches, J. Electroce.ram, Vol. 39, No. 1-4, pp. 239-250.

17. Baumgart, M. and Tortschanoff, A. (2013), Design rules for a compact and low-cost optical position sensing of MOEMS tilt mirrors based on a Gaussian-shaped light source, Proceedings of SPIE - The International Society for Optical Engineering Modeling Aspects in Optical Metrology IV, Vol. 8789, pp. 87890A. 
18. Selivanova, K.G., Avrunin, O.G. and Zlepko, S.M. (2019), Virtual training system for tremor prevention, Information Technologies in Medical Diagnostics II, pp. 9-14. ISBN 978-0-367-17769-0.

19. Noell, W., Weber, S., Masson, J., Extermann, J., Bonacina, L. and Bich, A. (2011), Shaping light with MOEMS, Proceedings of SPIE - The International Society for Optical Engineering Miniaturized Systems X, Vol. 7595, pp. 79300-00.

20. Nevliudov, I., Maksymova, S., Funkendorf, A., Chala, O. and Khrustalev, K. (2018), Using MEMS to adapt ultrasonic welding processes control in the implementation of modular robots assembly processes, XIV-th International Conference Perspective Technologies and Methods in MEMS Design (MEMSTECH), pp. 223-226.

21. Filipenko, O., Chala, O. and Sychova, O. (2018), Some Issues of Dependencies of Loss from Technological Features of Optical Switches for Communication Systems, International Scientific-Practical Conference Problems of Infocommunications. Science and Technology (PIC S\&T), Kharkiv, Ukraine, pp. 599-603. https://doi.org/10.1109/INFOCOMMST.2018.8632051.

22. Gierster, L., Ünal, AA., Pape, L., Radu, F. and Kronast, F. (2015), Laser induced magnetization switching in a TbFeCo ferrimagnetic thin film: Discerning the impact of dipolar fields laser heating and laser helicity by XPEEM, Ultramicroscopy, Vol. 159, pp. 508-512. https://doi.org/10.1016/j.ultramic.2015.05.016.

23. Hong, Y.K. (2007), Dynamic Response Modeling of MEMS Micromirror Corner Cube Reflectors With Angular Vertical Combdrives, Journal of lightwave technology, Vol. 25, No. 2, pp. 472-480.

24. Zhao, Y., Chen, M., Xia, F., Cai, L. and Li, X. (2017), Small Curvature Sensor Based on Butterfly-Shaped MachZehnder, Interferometer. IEEE Trans Electron Devices, Vol. 64, No. 11, pp. 4644-4649.

25. Kim, M and Choi, K.C. (2017), Resistive Switching Characteristics of A12O3 Film for Transparent Nonvolatile Memory, IEEE Trans Nanotechnol, Vol. 16, No. 6, pp. 1129-1131.

26. McAneny, James J., Kennedy, M. and McGroggan, T. (2010), Advances in photonic MOEMS-MEMS device thinning and polishing, Proceedings of SPIE - The International Society for Optical Engineering Micromachining and Microfabrication Process Technology X, Vol. 7590, pp. 75900-00.

27. Plander, I. and Stepanovsky, M. (2007), Multi-physics Model of MOEMS-based Switch for All-Optical Interconnection Networks, 2007 Photonics in Switching, San Francisco, CA, pp. 85-86. https://doi.org/10.1109/PS.2007.4300762.

28. Murphy, Paul E. and Hall, Christopher A. (2015), Considerations in the evaluation and correction of mid-spatial frequency surface features, Proc. SPIE 9633, Optifab 2015, 96330F. https://doi.org/10.1117/12.2197037.

29. SE "Ukrainian Research and Training Center for Standardization, Certification and Quality" (2019), DSTU ISO 101108:2018 Optyka y optycheskye prybory. Razrabotka chertezhei optycheskykh elementov y system. Chast 8. Tekstura poverkhnosty, sherokhovatost y volnystost (ISO 10110-8:2010, IDT).

\section{Список літератури}

1. Филипенко О.І. Технологічні дефекти виробництва кремнієвих підкладок для функціональних відбиваючих поверхонь МОЕМС-перемикачів / О.І. Филипенко, О.О. Чала, М.I. Відешин // Системи управління, навігації та зв'язку. Збірник наукових праць. - Полтава: ПНТУ, 2017. - № 2(42). - С. 61-63.

2. Филипенко O.I. Технологічні фактори виробництва, що впливають на якість покриттів дзеркальних поверхонь МОЕМС-перемикачів / О.І. Филипенко, О.О. Чала, М.І. Відешин // Наукові нотатки. - 2017. - Вип. 57. - С. 178-183.

3. Васильев В.Н. Компьютерная обработка сигналов в приложении к интерферометрическим системам / В.Н. Васильев, И.П. Гуров. -СПб.: БХВ-Санкт-Петербург, 1998. - 237 с.

4. Jiang Y. Adaptive Interference Cancellation System with Different Correlation Control Methods / Y. Jiang, W. Ma, Z. Zhao // 2009 International Conference on Intelligent Human-Machine Systems and Cybernetics. - Hangzhou, Zhejiang, 2009. - P. 372-375. https://doi.org/10.1109/IHMSC.2009.216.

5. Suarez J. Methods of Feedback Control for Adaptive Counter-Phase Optical Interference Cancellation / J. Suarez, K. Kravtsov, P.R. Prucnal // IEEE Transactions on Instrumentation and Measurement. - 2011. - Vol. 60. - No. 2. - P. $598-607$. https://doi.org/10.1109/TIM.2010.2051058.

6. Филипенко O.I. Конструктивнотехнологічні фактори втрат в оптичних перемикачах на основі MOEMSкомпонентів / О.І. Филипенко, О.О. Чала // Міжнародна науково-практична конференція "Радіотехнічні поля, сигнали, апарати та системи", 10-16 березня 2014 року. - Київ, Україна.

7. Adaptive feedback interference cancellation system (AF-ICS) / S.J. Kim, J.Y. Lee, J.C. Lee, J.H. Kim, B.Lee N.Y. Kim // Proc. IEEE MTT-S Int. Microw. Symp. Dig. - 2003. - Vol. 1. - P. 627-630.

8. MOEMS for adaptive optics / J.H. Comtois, M.A. Michalicek, N. Clark and W. Cowan // 1998 IEEE/LEOS Summer Topical Meeting. Digest. Broadband Optical Networks and Technologies: An Emerging Reality. Optical MEMS. Smart Pixels. Organic Optics and Optoelectronics (Cat. No.98TH8369). - Monterey, CA, USA, 1998. - P. II/95-II/96. https://doi.org/10.1109/LEOSST.1998.689742.

9. Kurihara K. Polymer MOEMS mirror by all vacuum-less processes combining printed film and injection molding replication / K. Kurihara, H. Takagi and R. Maeda // 2012 Symposium on Design, Test, Integration and Packaging of MEMS/MOEMS. - Cannes, 2012. - P. 200-203.

10. Modeling MEMS Membranes Characteristics / I. Nevliudov, V. Bortnikova, O. Chala, S. Maksymova // 2018 XXVI-th International Ukrainian-Polish Scientific and Technical Conference CAD in machinery design implementation and educational issues (CADMD). - 2018. - P. 61-68.

11. Unamuno A. Hybrid MOEMS tunable filter for interrogation of fiber Bragg grating sensors / A. Unamuno, D. Uttamchandani // IEEE Photonics Technology Letters. - 2005. - Vol. 17. - No. 1. - P. $202-204$. https://doi.org/10.1109/LPT.2004.837746.

12. Filipenko A.I. A Method for Analyzing Radiation Intensity and Its Application to Manufacture of Fiber Optic Components / A.I. Filipenko // Telecommunications and Radio Engineering. - 1998. - Vol. 52. - № 12. 
13. Joannopoulus J.D. Photonic Crystals / J.D. Joannopoulus, R.D. Meade, J.N. Winn. - Princeton University Press, 1995.

14. Optical position detection for MOEMS scanner mirrors with arbitrary trajectories / A. Tortschanoff, M. Baumgart, D. Holzmann, C. Mayer, T. Sandner, A. Kenda // 2014 International Conference on Optical MEMS and Nanophotonics. Glasgow, 2014. - P. 135-136.

15. Impact of Technological Operations Parameters on Moems Components Formation / O. Filipenko, O. Chala, V. Bortnikova, O. Sychova, I. Botsman // 2019 IEEE 8th International Conference on Advanced Optoelectronics and Lasers (CAOL). - Sozopol, Bulgaria, 2019. - P. 371-374. https://doi.org/10.1109/CAOL46282.2019.9019570.

16. Optical memristive switches / U. Koch, C. Hoessbacher, A. Emboras, J. Leuthold // J. Electroce.ram. - 2017. - Vol. 39. No. 1-4. - P. 239-250.

17. Baumgart M. Design rules for a compact and low-cost optical position sensing of MOEMS tilt mirrors based on a Gaussian-shaped light source / M. Baumgart, A. Tortschanoff // Proceedings of SPIE - The International Society for Optical Engineering Modeling Aspects in Optical Metrology IV. - 2013. - Vol. 8789. - P. 87890A.

18. Virtual training system for tremor prevention / K.G. Selivanova, O.G. Avrunin, S.M. Zlepko et al. // Information Technologies in Medical Diagnostics II.ISBN 978-0-367-17769-0. - 2019. - P. 9-14.

19. Shaping light with MOEMS / W. Noell, S. Weber, J. Masson, J. Extermann, L. Bonacina, A. Bich // Proceedings of SPIE - The International Society for Optical Engineering Miniaturized Systems X. - 2011. - Vol. 7595. - P. 79300-00.

20. Using MEMS to adapt ultrasonic welding processes control in the implementation of modular robots assembly processes / I. Nevliudov, S. Maksymova, A. Funkendorf, O. Chala, K. Khrustalev // XIV-th International Conference Perspective Technologies and Methods in MEMS Design (MEMSTECH). - 2018. - P. 223-226.

21. Filipenko O. Some Issues of Dependencies of Loss from Technological Features of Optical Switches for Communication Systems / O. Filipenko, O. Chala, O. Sychova // 2018 International Scientific-Practical Conference Problems of Infocommunications. Science and Technology (PIC S\&T). - Kharkiv, Ukraine, 2018. - P. 599-603. https://doi.org/10.1109/INFOCOMMST.2018.8632051.

22. Laser induced magnetization switching in a TbFeCo ferrimagnetic thin film: Discerning the impact of dipolar fields laser heating and laser helicity by XPEEM / L. Gierster, AA. Ünal, L. Pape, F. Radu, F. Kronast // Ultramicroscopy. - 2015. Vol. 159. - P. 508-512. https://doi.org/10.1016/j.ultramic.2015.05.016.

23. Hong Y.K. Dynamic Response Modeling of MEMS Micromirror Corner Cube Reflectors With Angular Vertical Combdrives / Y.K. Hong // Journal of lightwave technology. - 2007. - Vol. 25. - No. 2. - P. 472-480.

24. Small Curvature Sensor Based on Butterfly-Shaped Mach-Zehnder / Y. Zhao, M. Chen, F. Xia, L. Cai, X. Li // Interferometer. IEEE Trans Electron Devices. - 2017. - Vol. 64. - No. 11. - P. 4644-4649.

25. Kim M. Resistive Switching Characteristics of Al2O3 Film for Transparent Nonvolatile Memory / M. Kim, K.C. Choi // IEEE Trans Nanotechnol. - 2017. - Vol. 16. - No. 6. - P. 1129-1131.

26. McAneny James J. Advances in photonic MOEMS-MEMS device thinning and polishing / J. James McAneny, M. Kennedy, T. McGroggan // Proceedings of SPIE - The International Society for Optical Engineering Micromachining and Microfabrication Process Technology X. - 2010. - Vol. 7590. - P. 75900-00.

27. Plander I. Multi-physics Model of MOEMS-based Switch for All-Optical Interconnection Networks / I. Plander, M. Stepanovsky // 2007 Photonics in Switching, San Francisco, CA. - 2007. $-\quad$ pp. 85-86. https://doi.org/10.1109/PS.2007.4300762.

28. Murphy Paul E. Considerations in the evaluation and correction of mid-spatial frequency surface features / Paul E. Murphy, Christopher A. Hall // Proc. SPIE 9633, Optifab 2015, 96330F (11 October 2015). https://doi.org/10.1117/12.2197037.

29. ДСТУ ISO 10110-8:2018 Оптика и оптические приборы. Разработка чертежей оптических элементов и систем. Часть 8. Текстура поверхности, шероховатость и волнистость (ISO 10110-8:2010, IDT) [Текст]. Введ. 2019-01-01. - ГП "Украинский научно-исследовательский и учебный центр проблем стандартизации, сертификации и качества” (ГП “УкрНИУЦ”).

\section{Відомості про авторів:}

\section{Невлюдов Ігор Шакирович}

доктор технічних наук професор

завідувач кафедри

Харківського національного

університету радіоелектроніки,

Харків, Україна

https://orcid.org/0000-0002-9837-2309

\section{Филипенко Олександр Іванович}

доктор технічних наук професор

професор кафедри

декан факультету Харківського національного

університету радіоелектроніки,

Харків, Україна

https://orcid.org/0000-0002-3886-9057

\section{Information about the authors:}

\author{
Igor Nevliudov \\ Doctor of Technical Sciences Professor \\ Head of Department \\ of Kharkiv National University \\ of Radio Electronics, \\ Kharkiv, Ukraine \\ https://orcid.org/0000-0002-9837-2309
}

\author{
Alexander Filipenko \\ Doctor of Technical Sciences Professor \\ Professor of Department \\ Dean of the Faculty of Kharkiv National \\ University of Radio Electronics, \\ Kharkiv, Ukraine \\ https://orcid.org/0000-0002-3886-9057
}


Чала Олена Олександрівна

асистент кафедри

Харківського національного

університету радіоелектроніки,

Харків, Україна

https://orcid.org/0000-0003-2454-3774

\section{Боцман Ірина Володимирівна}

кандидат технічних наук доцент кафедри

Харківського національного

університету радіоелектроніки,

Харків, Україна

https://orcid.org/0000-0003-1110-9602
Olena Chala

Assistant of Department

of Kharkiv National

University of Radio Electronics,

Kharkiv, Ukraine

https://orcid.org/0000-0003-2454-3774

Iryna Botsman

$\mathrm{PhD}$ (Engineering Sciences) Senior Lecturer

of Kharkiv National

University of Radio Electronics,

Kharkiv, Ukraine

https://orcid.org/0000-0003-1110-9602

\section{МЕТОД КОНТРОЛЮ ФУНКЦІОНАЛЬНИХ ПОВЕРХОНЬ КОМПОНЕНТІВ МІКРООПТОЕЛЕКРОМЕХАНІЧНИХ СИСТЕМ}

І.Ш. Невлюдов, О.І. Филипенко, О.О. Чала, І.В. Боцман

Предметом статті є метод комп 'ютерної обробки сигналів інтерференційних зображень функиіональних поверхонь компонентів мікроелектромеханічних систем. Метою є підвищення точності та зниження трудомісткості контролю при розробиі технології виробництва компонентів мікрооптоелекромеханічних систем. Завдання: аналіз технологічних особливостей виробниитва функиіональних компонентів мікрооптомеханічних систем та розробка методу контролю для підтвердження теоретичних досліджень виконаних на попередніх етапах роботи для визначення топології поверхонь на основі відфільтрованих, засобами комп'ютерного моделювання екстремумів, смуг, зображень інтерференційних функиіональних поверхонь МОЕМС, проведення експерименту для отримання апробації методу та отримання статистичних даних оцінки зразків поверхонь. Використовуваними методами є: методи планування експерименту та комп'ютерної обробки експериментальних даних, з використанням рядів Фур'є, перетворення Гілберта та смугових фільтрів. Отримані такі результати. Для контролю функиіональних поверхонь МОЕМС-компонентів запропоновано використовувати фазовий метод, який дозволяє швидко та точно проводити чисельну оцінку параметрів шорсткості зразків. Даний метод має досить високу точність, за рахунок виключення супутніх складових в сигналах, широкі функиіональні можливості, не потребує використання специфічного обладнання, дозволяє аналізувати характеристики поверхонь та отримувати їх тривимірне зображення. Висновки. Наукова новизна отриманих результатів полягає в наступному. Розроблений метод сприяє удосконаленню операиії контролю функиіональних поверхонь МОEMC, за рахунок використання інтерференційного методу, в якому на відміну від існуючих, запропоновано використовувати смуговий фільтр для усунення супутніх складових в інтерференційному сигналі, щяо дозволяє підвищити точність та знизити трудомісткість контролю.

Ключові слова: інтерференційний метод, контроль, функиіональний компонент, смуговий фільтр, МОЕМС.

\section{МЕТОД КОНТРОЛЯ ФУНКЦИОНАЛЬНЫХ ПОВЕРХНОСТЕЙ КОМПОНЕНТОВ МИКРООПТОЕЛЕКРОМЕХАНИЧНИХ СИСТЕМ}

\section{И.Ш. Невлюдов, А.И. Филипенко, А.А. Чала, И.В. Боцман}

Предметом статьи является метод компьютерной обработки сигналов интерференционных изображений функииональных поверхностей компонентов микроэлектромеханических систем. Целью является повышение точности и снижение трудоемкости контроля при разработке технологии производства компонентов микрооптоелекромеханичних систем. Задачи: анализ технологических особенностей производства функииональных компонентов микрооптомеханичних систем и разработка метода контроля для подтверждения теоретических исследований, выполненных на предыдущих этапах работы для определения топологии поверхностей на основе отфильтрованных, средствами компьютерного моделирования экстремумов, полос, изображений интерферениионных функииональных поверхностей МОЭМС, проведение эксперимента для получение апробации метода и получения статистических данных оценки образиов поверхностей. Используемыми методами являются: методы планирования эксперимента и компьютерной обработки экспериментальных данных с использованием рядов Фурье, преобразования Гилберта и полосных фильтров. Получены следуюшие результаты. Для контроля функииональных поверхностей МОЭМС-компонентов предложено использовать фазовый метод, который позволяет быстро и точно проводить численную оценку шероховатости образиов. Данный метод имеет достаточно высокую точность за счет исключения сопутствующих составляющих в сигналах, широкие функииональные возможности, не требует использования специфического оборудования, позволяет анализировать характеристики поверхностей и получать их трехмерное изображение. Выводы. Научная новизна полученных результатов заключается в следующем. Разработанный метод способствует совершенствованию операции контроля функииональных поверхностей МОЭМС, за счет использования интерференционного метода, в котором в отличие от существуюших, предложено использовать полосовой фильтр для устранения сопутствуюших составляющих в интерференционной сигнале, позволяет повысить точность и снизить трудоемкость контроля.

Ключевые слова: интерференционный метод, контроль, функииональный компонент, полосовой фильтр, МОЭМС. 